\title{
Utilización de bagazo de la industria cervecera para la producción de ladrillos para construcción
}

\section{Utilization of bagasse from the beer industry in clay brick production for building}

\author{
M. L. Martínez ${ }^{(*)}$, D. Eliche(*), N. Cruz(*), F. A. Corpas(*)
}

Recepción/Received: 26-X-10

Aceptación/Accepted: 14-VI-11

Publicado online/Online publishing: 07-II-12

RESUMEN

Este estudio analiza ladrillos fabricados a partir de bagazo, un subproducto del sector cervecero. Las materias primas (arcilla y bagazo) fueron caracterizadas para determinar la composición química, la composición mineralógica y el comportamiento térmico. Las mezclas fueron preparadas adicionando cantidades del $0 ; 2,5 ; 5$; 7,5 y $10 \%$ en peso de bagazo a la arcilla. Se obtuvieron piezas rectangulares por aplicación de una presión de $54,5 \mathrm{MPa}$, secadas a $110^{\circ} \mathrm{C}$ y sinterizadas a $950{ }^{\circ} \mathrm{C}$ en un horno mufla durante 1 hora. Las propiedades cerámicas relativas a la pérdida de peso por calcinación, contracción lineal, densidad aparente, densidad absoluta, absorción de agua, succión del agua y resistencia a la compresión fueron analizadas para evaluar la conveniencia de utilizar estos residuos en matrices cerámicas para la producción de ladrillos para construcción. Los resultados indican que la incorporación de bagazo disminuye las densidades aparente y absoluta, incrementa la absorción de agua y reduce la resistencia a la compresión del ladrillo.

Palabras clave: arcilla, bagazo, reciclado, ladrillos cerámicos.

\section{SUMMARY}

This study analyzes bricks manufactured from bagasse, a by-product of the brewing industry. Raw materials (clay and bagasse) were characterized to determine their chemical composition, mineralogical composition and thermal behaviour. Mixtures were prepared with amounts of 0, 2.5, 5, 7.5 and $10 w t \%$ of bagasse incorporated into the clay body. Rectangular test pieces were obtained by application of 54.5 MPa pressure, they were dried at $110^{\circ} \mathrm{C}$ and fired at $950^{\circ} \mathrm{C}$ in a laboratory furnace for 1 hour. Ceramic properties related to weight loss on ignition, linear shrinkage, bulk and absolute density, water absorption, water suction and compressive strength were analyzed in order to evaluate the suitability of using this wastes in ceramic matrix to the production of building bricks. The results indicate that the incorporation of the bagasse decreases the absolute and bulk density, increases the water absorption and reduces the compressive strength of the brick.

Keywords: clay, bagasse waste, recycling, ceramic bricks.

(*) Universidad de Jaén, Linares, Jaén (España). 


\section{INTRODUCCIÓN}

Más de 850 millones de toneladas de residuos industriales son producidos al año en Europa, con una tasa de crecimiento anual del $3 \%$. Entre las medidas que están siendo consideradas para reducir este hecho, está la incorporación de residuos industriales en nuevos productos, lo que conlleva ampliar el ciclo de vida de los materiales (1). En respuesta al crecimiento exponencial de residuos en los últimos años (2), la UE promueve la prevención o minimización y reciclado de residuos en relación al uso de tecnologías limpias y la gestión de residuos.

Autores como Khoo (3), que ha estudiado el impacto del ciclo de vida de tecnologías de conversión de varios residuos, creen que la política clave de la gestión de residuos de una nación pasa por otorgar prioridad absoluta al reciclado, recuperación y reutilización de materiales residuales. Hartlén (4) analiza las consecuencias ambientales del uso de residuos y sugiere que se utilizen materiales no peligrosos en procesos, para que a posteriori sea posible la utilización del residuo. Ashby (5) también evalúa los mecanismos del desarrollo de materiales en el siglo XXI y concluye que se está creando la necesidad de adaptar diseño y materiales, lo que resulta primordial para restaurar el equilibrio con el medio ambiente.

La industria de la construcción y sus auxiliares pueden recepcionar residuos y subproductos. Dado que estas industrias manejan materiales a gran escala, pueden incluir un porcentaje significativo de residuos en la composición de los materiales que utilizan. Varios tipos de residuo están siendo usados para fabricar materiales de construcción, tales como lodos de depuradora (6-7), residuos de los procesos de generación de energía (8), restos de la industria agroalimentaria (9), otros materiales orgánicos (10), etc. Con una tasa de generación de bagazo próxima al medio millón de toneladas al año, la industria cervecera genera una cantidad significativa de residuo que puede ser utilizada en la fabricación de materiales de construcción (11).

En la industria cervecera, los subproductos de naturaleza orgánica constituyen el mayor grupo desde un punto de vista del volumen generado. La generación de bagazo (restos de malta procesada) es particularmente abundante. A causa de que la malta es la materia prima más comúnmente utilizada en la producción de cerveza $(1,66-$ $2,082 \mathrm{~kg} / \mathrm{m}^{3}$ cerveza embotellada), no sorprende que se produzcan cantidades de este orden de magnitud.

El bagazo es generado tras la maceración en la etapa de filtrado, en los filtros tanque o filtros prensa. Aunque el bagazo puede ser valorado por ganaderos en regiones próximas a cervecerías para alimentación del ganado, esto solo supondría una salida para el bagazo

\section{INTRODUCTION}

More than 850 million tons of industrial wastes are produced in Europe, with a 3\% annual growth rate. Among the measures being considered to reduce this figure is the incorporation of industrial waste in new products, which leads to broader life cycles of materials (1). In response to the exponential growth of waste in recent years (2), the EU promotes prevention or minimization and recycling of waste relative to the use of clean technologies and waste management.

Authors like Khoo (3) who has studied the life cycle impact of various waste conversion technologies, believe that the nation's key policy for waste management gives top priority to the recycling, recovery and reuse of waste materials. Hartlén (4) analyses the environmental consequences of using residues and suggests that no hazardous chemicals should be used in the process that later make it impossible to utilise the residue. Ashby (5) also assesses drivers of material development in the 21st century and concludes that we are creating the need to adapt design and materials that is fundamental to restore equilibrium with the environment.

The construction industry and its auxiliaries can receive waste and by-products. As these industries handle materials on a large scale, they can include a significant percentage of waste in the composition of used materials. Various waste types are being used for the manufacture of construction materials, such as sewage sludge waste (6-7), waste products in power generation processes (8), agri-food industry remains (9), other organic materials (10), etc. With a rate of generation of bagasse at about half a million tons per year, the brewing industry generates a significant amount of waste that can be used for the manufacture of construction materials (11).

In the brewing industry, by-products of organic nature constitute the major group from the perspective of generated volume. The generation of bagasse (the remains of processed malt) is particularly abundant. Because malt is most commonly used as raw solid in the production of beer $\left(1.66-2.082 \mathrm{~kg} / \mathrm{m}^{3}\right.$ bottled beer), it is not surprising that the industry is producing quantities of this order of magnitude.

The bagasse is generated after the maceration process in the filtrate stage, in the filter tanks or the filter press. Although bagasse can be a valuable by-product for cattle dealers in regions close to breweries for supplying of the cattle, it is not find an outlet for bagasse 
producido en instalaciones localizadas en áreas donde no haya pasto.

La tasa de generación de bagazo estará condicionada por la materia prima usada, por el tipo de cerveza fabricada, por los estándares de producto y por el funcionamiento del proceso. La cantidad de subproducto generado dependerá en gran medida de la humedad final del bagazo que puede fluctuar entre $65-81 \%$, lo que depende a su vez de la técnica de filtración utilizada (12).

Esta investigación busca una más alta comprensión y conocimiento sobre la preparación de productos cerámicos usando un residuo orgánico (bagazo) como aditivo a la matriz de arcilla, para fabricar materiales aptos para la construcción y conseguir como objetivo la eliminación y valorización del residuo. Para ello, fueron realizadas las siguientes etapas: 1) caracterización de las materias primas por métodos físico-químicos; 2) caracterización de las probetas preparadas con arcilla y bagazo para evaluar su calidad mediante la medida de la densidad, la resistencia a la compresión, absorción y succión de agua; 3) análisis comparativo del producto cerámico elaborado, teniendo en cuenta su composición (cantidad de bagazo adicionado).

\section{MATERIALES Y MÉTODOS}

\subsection{Preparación de las muestras}

El bagazo fue originado en la planta de fabricación de cerveza de la ciudad de Jaén. Fue secado durante 24 horas a $90^{\circ} \mathrm{C}$ en estufa eléctrica para eliminar la humedad. La arcilla fue obtenida por mezcla de tres tipos de arcilla en partes iguales: arcilla roja, blanca y negra, suministrada por una cantera de arcilla localizada en Bailén (España). Para asegurar un tamaño uniforme de partícula, tanto el bagazo como la arcilla fueron molidos y tamizados para obtener un polvo con tamaño de partícula adecuado para atravesar un tamiz de $150 \mu \mathrm{m}$.

Para determinar el efecto de la formación de poros por el material orgánico residual en la matriz de arcilla, se adicionaron diferentes cantidades de bagazo (2,5 a $10 \%$ en peso) a la arcilla. Para obtener resultados comparativos, diez muestras por serie fueron preparadas para los análisis. Las mezclas homogeneizadas en un mezclador fueron moldeadas bajo una presión de 54,5 MPa, usando una prensa de laboratorio uniaxial tipo Mega KCK-30. La cantidad de agua necesaria ( $8 \%$ en peso) para el mezclado fue adicionada para obtener una adecuada plasticidad y para eliminar defectos en la etapa de compresión. Probetas libres de bagazo (solo de arcilla) fueron realizadas como referencia. Se obtuvieron ladrillos sólidos con una sección transversal de 30 x $10 \mathrm{~mm}$ y una longitud de $60 \mathrm{~mm}$. Las muestras formadas fueron secadas produced by facilities located in areas where there is no grazing.

The generation rate of bagasse will be conditional on the raw material used, the type of made beer, product standards and process performance. The amount of the by-product generated will depend greatly on the final moisture of the bagasse that may fluctuate from 65$81 \%$ what at a time depends on the used filtration technique (12).

This investigation seeks a higher understanding and knowledge about the preparation of ceramic products using an organic waste (bagasse) as additive to the clay matrix for making apt materials for building and to get as aim the elimination and valorization of the waste. For that, the following stages were realized: 1) characterization of raw materials by physico-chemical methods; 2) characterization of prepared test pieces with clay and bagasse to evaluate their quality by measure of density, compressive strength, water absorption and suction; 3) comparative analysis of the elaborated ceramic product, taking into account their composition (amount of added bagasse).

\section{MATERIALS AND METHODS}

\subsection{Preparation of the samples}

The bagasse waste was originated at the beer manufacturing plant in the city of Jaén. It was dried for 24 hours at $90^{\circ} \mathrm{C}$ in an electric heater to remove moisture. The clay was obtained by mixing three types of raw clay in equal parts: red, white and black. The clay was supplied by a clay pit located in Bailén (Spain). To ensure uniform particle size, both bagasse and clay were crushed and ground to obtain a powder with a particle size suitable to pass through a $150 \mu \mathrm{m}$ sieve.

To determine the effect of the pore formation for organic waste material on the clay-matrix, different amounts of bagasse (2.5 to $10 \% \mathrm{wt}$ ) were added to the clay. To obtain comparative results, ten samples for series were prepared for the tests. Homogenized mixtures in a blender was moulded under 54.5 MPa of pressure, using a uniaxial laboratory press type Mega KCK-30 A. The necessary amount of water (8 wt\%) for mixing was added to obtain adequate plasticity and to eliminate defects in the compression stage. Bagasse-free test pieces (only clay) were made as a reference. Solid bricks with $30 \times 10 \mathrm{~mm}$ cross sections and a length of $60 \mathrm{~mm}$ were obtained. The shaped samples were dried for 48 hours at $110^{\circ} \mathrm{C}$ in the electric heater to reduce the moisture content. Dried samples were fired in a 
durante 48 horas a $110^{\circ} \mathrm{C}$ en estufa eléctrica para reducir el contenido de humedad. Las muestras secadas fueron sinterizadas en un horno mufla a la velocidad de $10^{\circ} \mathrm{C} / \mathrm{min}$ hasta $950^{\circ} \mathrm{C}$ durante 1 hora. Esta es la temperatura normalmente utilizada en la fabricación de ladrillos de arcilla. Las muestras fueron después enfriadas a temperatura ambiente por convección natural dentro del horno. Las muestras formadas fueron denominadas como $\mathrm{C}$ para el ladrillo sin bagazo y como C-xB para las mezclas, donde $x$ representa el porcentaje de bagazo (B) en la matriz de arcilla (C).

\subsection{Caracterización de las materias primas}

La difracción de rayos $X$ de la arcilla fue llevada a cabo usando un difractómetro automático Siemens D5000, con geometría Bragg-Brentano $(\theta / 2 \theta)$ y radiación $K \alpha 1,2$, equipado con un monocromador de grafito para eliminar la radiación $\mathrm{Cu} \mathrm{K} \beta$. Las composiciones químicas fueron determinadas por fluorescencia de rayos $\mathrm{X}$ (FRX) usando un equipo Philips Magix Pro (PW-2440).

El comportamiento térmico fue determinado mediante análisis termogravimétrico (ATG), análisis térmico diferencial (ATD) usando una termobalanza Rheometric Scientific STA 1500. Las muestras de 15 a 30 mg aproximadamente fueron colocadas en un crisol de platino y calentadas a la velocidad de $10^{\circ} \mathrm{C} / \mathrm{min}$ desde temperatura ambiente hasta $900^{\circ} \mathrm{C}$. El flujo de aire se mantuvo a lo largo de las medidas a la velocidad de $50 \mathrm{ml} / \mathrm{min}$. Los datos mostrados reflejan simultáneamente la pérdida de peso en función de la temperatura y el diagrama ATD.

El análisis químico elemental CHNS fue realizado para determinar en las muestras el contenido en carbono total, hidrógeno, nitrógeno y azufre usando un termoanalizador elemental CHNS-O Finnigan Flash EA 1112 vía combustión $\left(950^{\circ} \mathrm{C}\right.$ ) en atmósfera de $\mathrm{O}_{2}$.

El contenido de carbonatos en la arcilla fue determinado por calcimetría.

\subsection{Caracterización del ladrillo}

Las series de análisis e inspecciones fueron realizadas para determinar las propiedades físicas (pérdida de peso por calcinación, contracción lineal, densidades aparente y absoluta, absorción y succión de agua) y propiedades mecánicas (resistencia a la compresión) de los ladrillos, para asegurar el cumplimiento de las especificaciones reguladas se han seguido las normas UNE.

La pérdida de peso por calcinación fue obtenida por diferencia del peso tras las etapas de secado a $110^{\circ} \mathrm{C}$ y sinterizado a $950^{\circ} \mathrm{C}$. La contracción lineal fue obtenida por medida de la longitud de las muestras antes y después laboratory furnace at a rate of $10^{\circ} \mathrm{C} / \mathrm{min}$ up to $950^{\circ} \mathrm{C}$ for 1 hour. This temperature is normally used in the fabrication of clay bricks. Samples were then cooled to room temperature by natural convection inside the furnace. The shaped samples were designated as $C$ for the brick without bagasse and $C-x B$ for the mixtures, where $x$ denotes the percentage weight of bagasse $(B)$ in the matrix clay $(C)$.

\subsection{Characterization of brick raw material}

$X$-ray diffractometry of clay was carried out using an automatic diffractometer Siemens D5000, with BraggBrentano geometry $(\theta / 2 \theta)$ and $K \alpha 1,2$ radiation, equipped with a graphite monochromator to eliminate $\mathrm{Cu} K \beta$ radiation. Chemical composition was determined by $X$ ray fluorescence (XRF) using Philips Magix Pro (PW2440) equipment.

Thermal behaviour was determined by Thermogravimetric analysis (TGA) differential thermal analysis (DTA) using a Rheometric Scientific STA 1500 thermobalance. Samples of approximately 15 to $30 \mathrm{mg}$ were placed in a platinum crucible and heated at a rate of $10^{\circ} \mathrm{C} / \mathrm{min}$ in the range from room temperature to $900^{\circ} \mathrm{C}$. Air flow at was kept along the mesures a rate of $50 \mathrm{ml} / \mathrm{min}$. Shown data reflect loss of weight depending on temperature and DTA diagram simultaneously.

CHNS chemical elemental analysis was carried out to determine the total of carbon, hydrogen, nitrogen and sulphur in the samples by using a CHNS-O Thermo Finnigan Elementary Analyzer Flash EA 1112 via combustion $\left(950^{\circ} \mathrm{C}\right)$ in an $\mathrm{O}_{2}$ atmosphere.

The content of carbonates in the clay was determined by calcimetry.

\subsection{Characterization of the brick}

The series of tests and inspections were performed to determine physical properties (weight loss on ignition, linear shrinkage, bulk and absolute density, water absorption test and water suction) and mechanical properties (compressive strength) of the bricks, to ensure the fulfillment the regulated specification, the UNE standards have been followed.

Weight loss on ignition was obtained by difference between the weight after the drying stage at $110^{\circ} \mathrm{C}$ and after the firing stage at $950^{\circ} \mathrm{C}$. Linear shrinkage was obtained by measuring the length of the samples before 
de la etapa de sinterizado usando un calibre de precisión $\pm 0,01 \mathrm{~mm}$. La densidad aparente fue calculada como la relación entre la masa seca del ladrillo conformado y su volumen estándar. La densidad absoluta fue obtenida siguiendo la Norma UNE-EN 77213 (13).

La capacidad de absorción de agua se define como la medida de la humedad cuando un sólido (ladrillo, en este caso) está completamente inmerso en agua durante un tiempo. El análisis para determinar la capacidad de absorción del agua fue realizado según la Norma UNE 67027 (14).

La succión de agua de un ladrillo se mide como el volumen de agua absorbido durante un tiempo corto de inmersión parcial. El análisis para determinar la succión de agua fue realizado según la Norma UNE 67031 (15).

El efecto de la resistencia a la heladicidad fue determinado según la Norma UNE 67028 (16), por medio de un sistema manual en el que las muestras experimentaron 25 ciclos de congelación/descongelación (18 horas para congelación-8 horas para descongelación) usando un congelador. Las muestras previamente fueron sumergidas en agua durante 48 horas para alcanzar la saturación.

La microestructura de las piezas conformadas se observó por medio de microscopía electrónica de barrido, con un microscopio electrónico de alta resolución JEOL SM 840. Las muestras fueron colocadas en un pedestal de aluminio y metalizadas con oro usando un dispositivo JEOL JFC 1100 (fine coat ion sputter).

\section{RESULTADOS Y DISCUSIÓN}

\subsection{Análisis de las materias primas}

La composición química y la pérdida por calcinación (L.O.I.) de la arcilla y de las cenizas de bagazo se muestran en la Tabla 1. El patrón de difracción de rayos $X$ de la mezcla de arcilla en crudo, Figura 1a (1), indica que contiene principalmente cuarzo $\left(\mathrm{SiO}_{2}\right)$, con la presencia de calcita $\left(\mathrm{CaCO}_{3}\right)$ y dolomita $\left(\mathrm{CaMg}\left(\mathrm{CO}_{3}\right)_{2}\right)$. Pudiéndose observar también trazas de filosilicatos como moscovita, ortoclasa, faujasita, albita y clorita. El patrón de difracción de rayos $X$ de la arcilla cocida, Figura 1a (2), muestra que está compuesta principalmente por cuarzo, con cantidades mucho menores y en proporciones similares de diversos aluminosilicatos, calcita y hematita. El contenido de hematita de la arcilla cocida es más alto que el observado para la arcilla en crudo, lo que sugiere que parte de la hematita se forma a elevada temperatura, a expensas de los óxidos de hierro producidos por la descomposición de los filosilicatos. and after the firing stage using a calliper with a precision of $\pm 0.01 \mathrm{~mm}$. Bulk density was calculated as the ratio of the dry mass of the conformed brick and its standard volume. Absolute density was obtained according to Standard procedure UNE-EN 77213 (13).

Water absorption capacity is defined as the measurement of moisture when a solid (brick, in this case) is completely immersed in water for a long time. The test to determine water absorption capacity was implemented according to Standard procedure UNE 67027 (14).

Water suction of a brick is measured as the volume of water absorbed during a short partial immersion. The test to determine water suction was implemented according to Standard procedure UNE 67031 (15).

The effect of frost resistance was determined according to Standard UNE 67028 (16), by means of a manual system, in which samples underwent 25 icing/deicing cycles (18 hours for icing-8 hours for deicing) using a freezer. The samples had been immersed in water for the previous 48 hours to reach the saturation.

The microstructure of the conformed pieces is observed by means of a scanning electron microscope (SEM), with a high-resolution transmission electron microscope JEOL SM 840. The samples were placed on an aluminium grate and coated with gold using an ion sputtering device JEOL JFC 1100.

\section{RESULTS AND DISCUSSION}

\subsection{Analysis of raw materials}

The chemical composition and the loss on ignition (L.O.I.) of the clay and the bagasse ash are shown in Table 1. The XRD pattern of raw clay, Figure 1a (1) contained primarily quartz $\left(\mathrm{SiO}_{2}\right)$ with the presence of calcite $\left(\mathrm{CaCO}_{3}\right)$ and dolomite $\left(\mathrm{CaMg}\left(\mathrm{CO}_{3}\right)_{2}\right)$. We also see traces of phyllosilicates such as muscovite, orthoclase, faujasite, albite and chlorite. The XRD pattern of firing clay, Figure 1a (2), shows that it consists mostly of quartz; with much lower amounts of various aluminosilicates, calcite and hematite, in similar proportions. The hematite contents of the fired clay are higher than those observed in the raw clay, which suggests that part of the hematite observed is formed at high temperature, at the expense of iron oxides produced by the breakdown of the phyllosilicates. 
Tabla 1 / Table 1

Composición química de la mezcla de arcillas y de las cenizas del bagazo. Chemical composition of the clay and bagasse ash.

\begin{tabular}{|c|c|c|}
\hline Óxidos / Oxide content (\%) & Arcilla / Clay & Cenizas de bagazo / Bagasse ash \\
\hline $\mathrm{SiO}_{2}$ & 55.82 & 54.53 \\
\hline $\mathrm{Al}_{2} \mathrm{O}_{3}$ & 12.12 & 0.36 \\
\hline $\mathrm{Fe}_{2} \mathrm{O}_{3}$ & 4.83 & 0.19 \\
\hline $\mathrm{MnO}$ & 0.03 & 5.66 \\
\hline $\mathrm{MgO}$ & 1.49 & 7.75 \\
\hline $\mathrm{CaO}$ & 9.21 & 0.29 \\
\hline $\mathrm{Na}_{2} \mathrm{O}$ & 0.49 & 3.55 \\
\hline $\mathrm{K}_{2} \mathrm{O}$ & 2.78 & 0.06 \\
\hline $\mathrm{TiO}_{2}$ & 0.83 & 26.19 \\
\hline $\mathrm{P}_{2} \mathrm{O}_{5}$ & 0.12 & 0.09 \\
\hline $\mathrm{CuO}_{\mathrm{SrO}}$ & - & 0.07 \\
\hline $\mathrm{ZnO}$ & - & 0.12 \\
\hline $\mathrm{Zr}(\mathrm{ppm})$ & - & - \\
\hline $\mathrm{LOI}$ & 279.3 & - \\
\hline
\end{tabular}

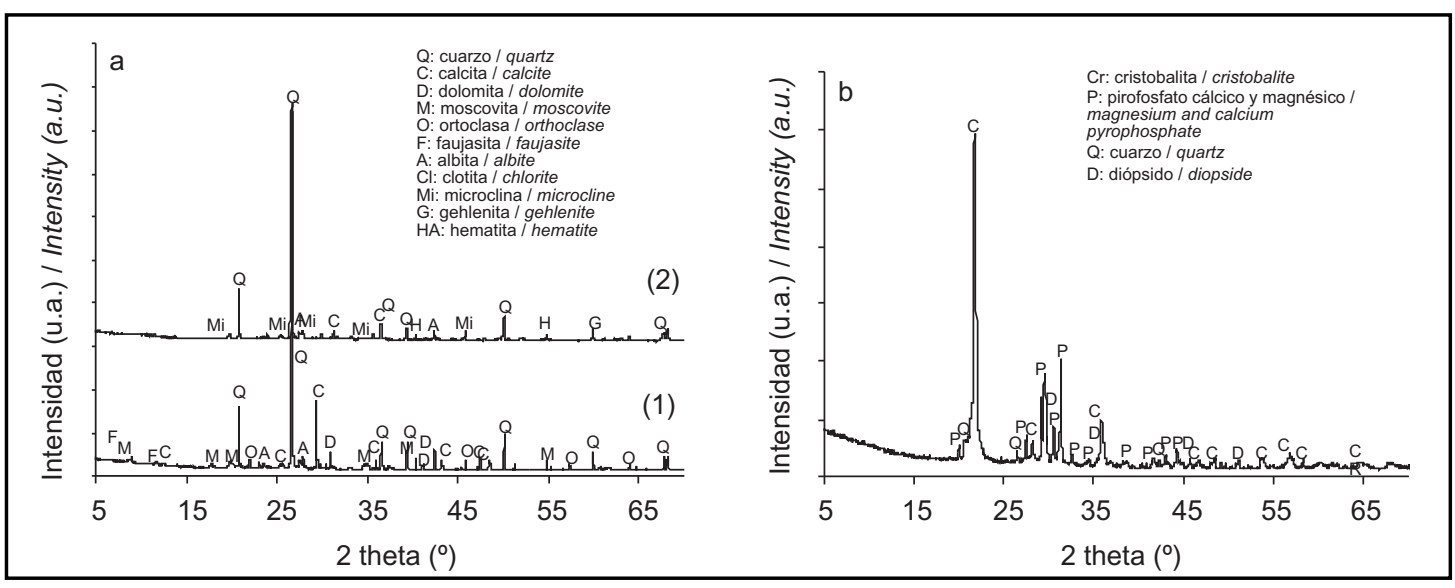

Figura 1. Patrones DRX para (a) arcilla pulverizada (1) cruda y (2) arcilla cocida; y (b) cenizas de bagazo. Figure. 1. DRX pattens for powdered (a) (1) raw clay and (2) fired clay; and (b) bagasse ash.

El patrón de difracción de rayos $X$ de las cenizas obtenidas después de la calcinación a $950^{\circ} \mathrm{C}$ del residuo bagazo (Figura 1b) se compone principalmente de cristobalita- $\alpha$ seguido en proporción por pirofosfato de magnesio y calcio. Como componentes menores incluyen cuarzo y diópsido. La presencia de cristobalita es un inconveniente en el uso de estos materiales, ya que reduce la resistencia de los materiales cocidos al choque térmico.

El ATG-ATD de la arcilla y del bagazo hasta $900{ }^{\circ} \mathrm{C}$ se muestra en la Figura 2. En el caso de la arcilla el calentamiento desde temperatura ambiente hasta $150^{\circ} \mathrm{C}$ con una pérdida de peso del 1,6\% produce la liberación del agua de hidratación, observándose un pico endotérmico a $60^{\circ} \mathrm{C}$. Desde los $150^{\circ} \mathrm{C}$ hasta los $600^{\circ} \mathrm{C}$, la pérdida de peso del $2 \%$ se puede asignar a reacciones de pirólisis (deshidroxilación de los hidróxidos de hierro y alumnio) y a reacciones de combustión. La curva de ATD
The XRD pattern of the ash obtained after burning the residue bagasse at $950^{\circ} \mathrm{C}$ consists mostly of cristobalite- $\alpha$ followed proportionally by magnesium and calcium pyrophosphate. Minor components include quartz and diopside. The presence of cristobalite is a drawback in the use of these materials, since it reduces the resistance of the fired bodies to thermal shock (Figure 1b).

TGA-DTA analysis of clay and bagasse up to $900^{\circ} \mathrm{C}$ are shown in Figure 2. In the case of clay heated from room temperature to $150^{\circ} \mathrm{C}$ with a weight loss of $1.6 \%$, the heating produces the release of hydration water, an endothermic peak has been found at $60^{\circ} \mathrm{C}$. From $150^{\circ} \mathrm{C}$ to $600{ }^{\circ} \mathrm{C}$, a weight loss of $2.0 \%$ can be assigned to pyrolysis (dehydroxylation of aluminium and iron hydroxides) and combustion reactions. The ATD curve shows a light endothermic peak centred to $565^{\circ} \mathrm{C}$ that 
muestra un ligero pico endotérmico centrado a $565^{\circ} \mathrm{C}$ que también podría asociarse a la transformación $\alpha \rightarrow \beta$ del cuarzo. Por último, en el intervalo de $600^{\circ} \mathrm{C}$ a $900^{\circ} \mathrm{C}$, la pérdida de peso del 9,5\% se debe probablemente a la descomposición de $\mathrm{CaCO}_{3}$, observándose un fuerte pico endotérmico a $780{ }^{\circ} \mathrm{C}$.

La curva de ATG-ATD del bagazo es típica de un combustible sólido. Se puede observar que el residuo puede ser totalmente combustionado en el cuerpo de la arcilla a bajas temperaturas y en el amplio intervalo de 200$700{ }^{\circ} \mathrm{C}$. Se observan dos picos exotérmicos y una pérdida de peso por reacciones de combustión. La pérdida total de peso es del $96,8 \%$, lo que indica que en la combustión apenas se producen cenizas.

Los resultados del análisis ATG están de acuerdo con el análisis elemental CNHS, que muestra un alto contenido de carbono $(48,1 \%)$ e hidrógeno $(7,6 \%)$, lo que explica el alto poder calorífico del residuo. La potencia calorífica superior (PCS) puede calcularse a partir de la composición elemental mediante la siguiente ecuación [1] propuesta por BOIE, que nos permite determinar el poder calorífico de un material a partir de su contenido en $\mathrm{C}, \mathrm{H}, \mathrm{O}, \mathrm{S}$ y $\mathrm{N}$ [1]: might be associated with the quartz $\alpha \rightarrow \beta$ transformation. Finally, in the interval from $600^{\circ} \mathrm{C}$ to $900^{\circ} \mathrm{C}$, the weight loss of $9.5 \%$ is probably due to the decomposition of $\mathrm{CaCO}_{3}$, a strong endothermic peak is found at $780{ }^{\circ} \mathrm{C}$.

The TGA-DTA curve of the bagasse is typical of a solid fuel. We observe that the residue can be totally combusted in the body of the clay at low temperatures in the wide range of $200-700^{\circ} \mathrm{C}$. Two exothermic peaks and weight loss are observed, due to combustions. The total loss of weight is $96.8 \mathrm{wt} \%$, which indicates that the combustion scarcely produces ashes.

The results of the TGA analysis agree with the CNHS elemental analysis, which shows a high content of carbon (48.1\%) and hydrogen (7.6\%), which explains the high calorific power of this waste. The higher heating value (HHV) can be evaluated from the elemental composition using the equation [1] proposed for BOIE (17), which allows us to determine the calorific power of the material from its content in $C, H, O, S$, and $N$ [1]:

$$
\mathrm{PCS}=84[\mathrm{C}]+227,65[\mathrm{H}]+26,5[\mathrm{O}]+25[\mathrm{~S}]+15[\mathrm{~N}]
$$

La ecuación no tiene más de un 1,5\% de error (17), donde $\mathrm{C}$ y $\mathrm{H}$ son el porcentaje en peso de carbono e hidrógeno en el bagazo seco y $\mathrm{O}=100-\mathrm{C}-\mathrm{H}$-cenizas. Esta ecuación se puede utilizar para determinar si la PCS del residuo puede contribuir significativamente a las necesidades de calor durante el proceso de fabricación. Por lo general, en la fabricación de ladrillos se incluyen algunos materiales que contienen materia orgánica, como el coque o el orujo de oliva, que proporcionan algunas de las necesidades caloríficas. El bagazo se podría utilizar para este propósito, ya que tiene como promedio una potencia calorífica superior de $6.971,8 \mathrm{kcal} / \mathrm{kg}$.
An equation that involves not more than $1.5 \%$ error where $\mathrm{C}$ and $\mathrm{H}$ for the percentage weight of carbon and hydrogen in the dry bagasse and $\mathrm{O}=100-\mathrm{C}-\mathrm{H}$-ash content. This equation can be used to determine whether the HHV of the waste can contribute significantly to the heat requirements during the fabrication process. Brick manufacturing usually includes some materials containing variable organic matter, such as coke or olive pomace, which provide some of the heating requirements. Bagasse could also be used for this purpose because it has an average higher heating value of $6971.8 \mathrm{kcal} / \mathrm{kg}$.

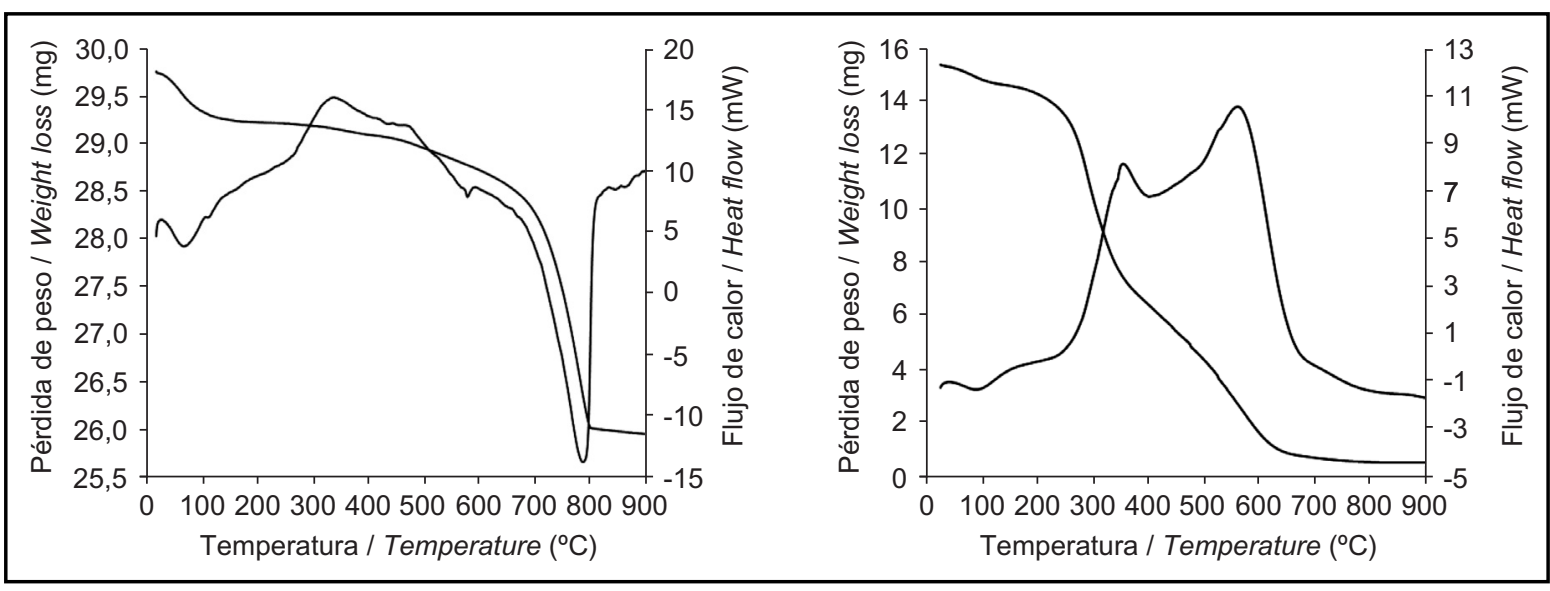

Figura 2. ATG-ATD de (a) arcilla y (b) bagazo.

Figure 2. TGA-DTA of (a) clay and (b) bagasse. 


\subsection{Caracterización de los materiales conformados}

La sinterización de los ladrillos produce cambios en la masa y dimensiones. La presencia de materia orgánica puede ocasionar defectos como el corazón negro si el carbón orgánico no combustiona completamente durante el proceso de cocción. Este defecto no se observa en estos ladrillos.

La calidad de los ladrillos se puede asegurar por el grado de contracción lineal. Normalmente, para que los ladrillos se consideren de buena calidad, la contracción lineal debe ser inferior al $8 \%$. Como se observa en la Tabla 2, la incorporación de bagazo cambia la contracción lineal de la arcilla. La contracción lineal de las muestras se incrementa desde el $-0,58 \%$ para la arcilla, hasta el valor $-1,19 \%$ para los ladrillos C-5B. Aunque los mecanismos de sinterización producen una mayor proximidad entre en las partículas y, por lo tanto, provocan la contracción, las probetas de arcilla así como las probetas que contienen bagazo se expanden ligeramente (de ahí el valor negativo) cuando son cocidas a $950^{\circ} \mathrm{C}$ indicando un comportamiento típico en cocción de pastas porosas donde la cantidad de líquido que se genera es pequeña. Esto puede ser debido al elevado contenido en cuarzo de la arcilla que es inerte en el intervalo de temperaturas estudiado que reduce la contracción de la pieza, así como al incremento de la porosidad originada por el elevado contenido en materia orgánica del bagazo.

La pérdida de peso por calcinación mide la diferencia de peso de las muestras antes y después del proceso de cocción. La pérdida de peso de los ladrillos de arcilla después de la cocción a $950{ }^{\circ} \mathrm{C}$ es del $10 \%$ y se puede atribuir principalmente a la materia orgánica de la arcilla, a la eliminación del agua estructural de los minerales de la arcilla, debido a reacciones de deshidroxilación, y a la descomposición del carbonato de calcio ( $8,8 \%$ en peso). La adición de cantidades crecientes de bagazo a la arcilla produce un incremento lineal en la pérdida de peso por calcinación, debido al alto contenido en materia

\subsection{Characterization of conformed materials}

The sintering of the bricks causes changes in the bricks' mass and dimensions. The presence of organic matter can sometimes cause defects such as black core if the organic carbon is not completely burnt during the firing process. No black core defect was observed for these bricks.

The quality of the brick can be further assured from the degree of linear firing shrinkage. Normally, a good quality of brick exhibits shrinkage of less than $8 \%$. The sintering mechanisms encourage greater proximity between in the particles and thus cause shrinkage. As shown in Table 2, the addition of bagasse changes the linear shrinkage of the clay. Linear shrinkage of samples increases from $-0.58 \%$ for clay bricks to a maximum of $-1.19 \%$ for $C-5 B$ bricks. Although, the sintering mechanisms produce a greater proximity between in particles and therefore they cause the contraction, the clay test pieces as well as the test pieces that contain bagasse expand (of there the negative value) slightly when they are cooked to $950^{\circ} \mathrm{C}$ indicating a typical behavior in sintering of porous paste where the amount of liquid that is generated is small. This can be due to the elevated quartz content of the clay that is inert in the rank of temperatures studied that reduces the contraction of the piece, as well as to the increase of the porosity caused by the elevated content in organic matter of the bagasse.

Weight loss on ignition is used to measure the weight difference in brick samples before and after firing. Weight loss of clay brick after firing at $950^{\circ} \mathrm{C}$ is $10 \%$ and can be attributed primarily to the organic matter in clay, the elimination of water content from clay mineral due to dehydroxylation reactions, and the decomposition of calcium carbonate $(8.8 \mathrm{wt} \%)$. Adding increasing amounts of bagasse to clay causes a linear increase in weight loss after sintering, due to the higher organic matter content of the waste. On average, weight loss after sintering increases by $12.5 \%$ when 2.5 wt $\%$ of

Tabla 2 / Table 2

Características físicas de los ladrillos para construcción elaborados con bagazo.

Physical characteristics of construction bricks made from bagasse.

\begin{tabular}{|c|c|c|c|c|c|}
\hline Muestra / Sample & $\begin{array}{c}\text { Bagazo (\% peso) / } \\
\text { Bagasse content } \\
\text { (wt \%) }\end{array}$ & $\begin{array}{c}\text { Contracción lineal / } \\
\text { Linear shrinkage } \\
(\%)\end{array}$ & $\begin{array}{c}\text { Pérdida peso por } \\
\text { calcinación / Weight } \\
\text { loss ignition (\%) }\end{array}$ & $\begin{array}{c}\text { Absorción de agua / } \\
\text { Absortion water (\%) }\end{array}$ & $\begin{array}{c}\text { Succión de agua / } \\
\text { Sucction water } \\
\left.\text { (g/cm } \mathbf{m}^{2} \mathbf{m i n}\right)\end{array}$ \\
\hline C & 0 & $-0.58 \pm 0.062$ & $10.0 \pm 0.060$ & $14.4 \pm 0.240$ & $0.14 \pm 0.030$ \\
\hline C-2,5B & 2,5 & $-0.98 \pm 0.070$ & $12.6 \pm 0.353$ & $15.6 \pm 0.405$ & $0.13 \pm 0.013$ \\
\hline C-5B & 5 & $-1.19 \pm 0.155$ & $14.8 \pm 0.356$ & $19.0 \pm 0.640$ & $0.14 \pm 0.028$ \\
\hline C-7,5B & 7,5 & $-1.11 \pm 0.067$ & $16.5 \pm 0.400$ & $21.0 \pm 0.495$ & $0.20 \pm 0.033$ \\
\hline C-10B & 10 & $-1.08 \pm 0.275$ & $19.1 \pm 0.444$ & $24.0 \pm 0.547$ & $0.27 \pm 0.033$ \\
\hline
\end{tabular}


orgánica del residuo. En promedio, la pérdida de peso por calcinación aumenta un $12,5 \%$ cuando se añade un $2,5 \%$ en peso del residuo bagazo, alcanzando el $19,0 \%$ cuando se adiciona un $10 \%$ en peso del residuo (véase Figura 2).

La absorción de agua es un factor clave que afecta a la durabilidad de los ladrillos y es una medida indirecta de la porosidad abierta (18). Se puede observar en la Tabla 2 que la adición de bagazo incrementa la absorción de agua en el cuerpo de la arcilla. Por ejemplo, la adición del $10 \%$ de bagazo aumenta un $60 \%$ la absorción de agua. Esto demuestra que los mecanismos de consolidación de partículas, tales como el estado sólido y la sinterización en fase líquida todavía no son muy eficaces para esta temperatura de cocción y contribuyen al aumento de la porosidad abierta (19). Estos resultados pueden ser explicados por el aumento de la pérdida de peso por calcinación que se produce con la adición de bagazo, que genera porosidad en el material cerámico. Cuando la mezcla absorbe más agua, los ladrillos tienen mayor porosidad abierta y un mayor tamaño de poro, lo que da lugar a una menor densidad como muestra el estudio SEM. Bajos valores de densidad y altos valores de absorción de agua son indicativos de materiales porosos.

La Figura 3 muestra la densidad absoluta y aparente de muestras cocidas a $950{ }^{\circ} \mathrm{C}$ para diferentes proporciones de bagazo adicionado. Se observa que las densidades absoluta y aparente de los ladrillos son inversamente proporcionales a la cantidad de bagazo incorporado a la mezcla. La principal razón de esta tendencia es la combustión de los residuos orgánicos durante el periodo de sinterización, que forma poros abiertos y cerrados en el cuerpo de la arcilla. La adición de un $2,5 \%$ en peso del residuo al cuerpo de la arcilla (C-2,5B) causa una disminución de $8,6 \%$ y $7,4 \%$ en la densidad aparente y absoluta, respectivamente. Sin embargo, la incorporación adicional de bagazo hasta el 10\% en peso (C-10B) reduce la densidad aparente y absoluta un waste bagasse is added and to $19.0 \%$ when the addition of waste is 10 wt\% (see Figure 2).

Water absorption is a key factor affecting the durability of bricks and is a measure of open porosity (18). This shows that particle consolidation mechanisms, such as solid state and phase liquid sintering are still not very effective for this firing temperature and contribute to higher open porosity (19). One can observe in Table 2 that bagasse increase in water absorption by the clay body. For example, the addition of 10 wt $\%$ of bagasse increases water absorption by $60 \%$. This result can be explained by the increase in weight loss that occurs with the addition of bagasse, which generates porosity in the ceramics. When the mixture absorbs more water, the brick exhibits higher open porosity and larger pore size, resulting in a light density as shown in SEM. Low density and high water absorption values are the indicative of porous materials.

Figure 3 shows the measurements of absolute and bulk density for different proportions of bagasse fired at $950^{\circ} \mathrm{C}$. We see that the absolute and bulk density of the bricks is inversely proportional to the quantity of bagasse added to the mixture. The main reason for this tendency is the combustion of the organic residues during the sidtering period, which forms open and closed pores in the body clay. Adding 2.5 wt\% of waste to the clay body (C-2.5B) caused an $8.6 \%$ and $7.4 \%$ decrease in apparent and absolute density, respectively. However, additional bagasse incorporation to $10 \mathrm{wt} \%$ (C-10B) reduced the bulk and absolute density a $29.1 \%$ and $24.5 \%$, respectively. According to these observations,

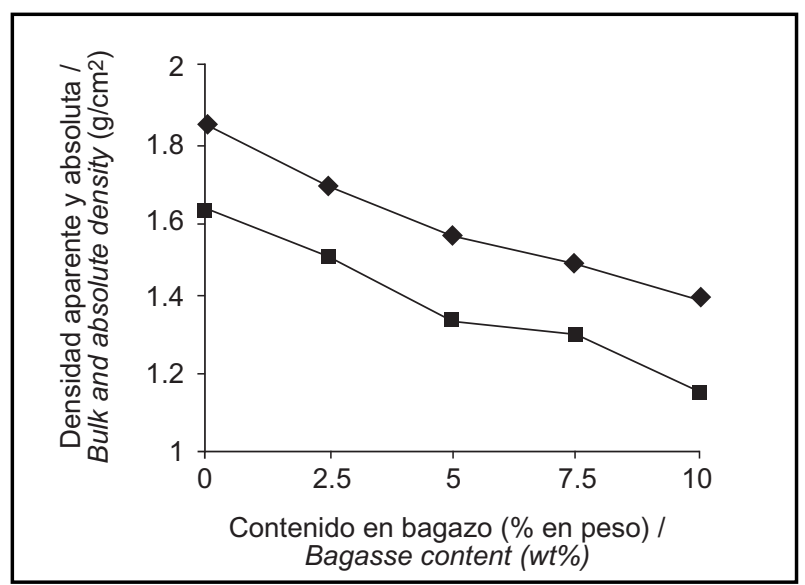

Figura 3. Densidad aparente $(\boldsymbol{\square})$ and densidad absoluta $(\bullet)$ de los ladrillos cocidos en función del bagazo añadido.

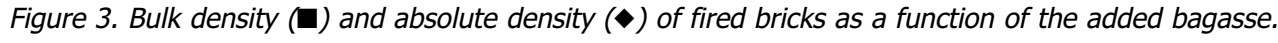


$29,1 \%$ y $24,5 \%$, respectivamente. De acuerdo con estos datos, la adición de altos contenidos de bagazo a la arcilla mejorará las propiedades térmicas del material, pero producirá un efecto negativo en las propiedades mecánicas, dando lugar a materiales con baja resistencia a la compresión y con tendencia a agrietarse fácilmente (20).

La succión de agua afecta a la calidad y durabilidad de los ladrillos. Los ladrillos con alto contenido en bagazo pueden tener defectos y una clara tendencia a la succión de agua y, por lo tanto, a una menor durabilidad. De acuerdo con la Norma UNE 67019, la succión de agua debe ser inferior a $0,45 \mathrm{~g} / \mathrm{cm}^{2} \mathrm{~min}$. Los resultados de la succión de agua se muestran en la Tabla 2. La succión de agua para la arcilla pura es $0,14 \mathrm{~g} / \mathrm{cm}^{2} \mathrm{~min}$. Este valor se mantiene hasta la incorporación del $5 \%$ en peso de residuo. Nuevas incorporaciones de bagazo del 7,5 y del $10 \%$ en peso en el cuerpo de la arcilla producen un aumento en la succión de agua obteniendo valores de 0,20 y $0,27 \mathrm{~g} / \mathrm{cm}^{2}$ min, respectivamente. Esto indica que la adición de contenidos elevados de residuo aumenta la porosidad interconectada superficial, de acuerdo con los datos de absorción. Las muestras con menor contenido de residuo $(2,5$ y $5 \%$ en peso) deben tener una mayor porosidad cerrada causada por la formación de poros no conectados.

El estudio morfológico de las probetas conteniendo arcilla, así como de las mezclas con pequeños y grandes contenidos en bagazo (C-2,5B\%, C-5B\% y C-10B\%), se ha obtenido por SEM como se muestra en la Figura 4.

Como se observa en las micrografías la porosidad de la arcilla (Figura 4a) tanto pequeña y cerrada (microporos), procedente de los poros intergranulares, como abierta (macroporos) debido a los poros situados en la superficie se ve modificada. Estos cambios son debidos a la presencia de bagazo. Pequeñas cantidades de bagazo $(2,5$ y $5 \%$ en peso) causan un incremento en la porosidad cerrada con poros regulares esféricos (Figuras $4 b$ y $4 c$ ), mientras que mayores cantidades de bagazo ( $>5 \%$ en peso) provocan un incremento en la porosidad abierta por conexión de los macroporos como muestran los datos de absorción de agua (Figura 4d).

Otros autores han estudiado la introducción de residuos orgánicos en la producción de ladrillos de arcilla. Gregorová et al. (9) estudiaron el uso de diferentes tipos de residuos conteniendo almidón (patata, trigo, mandioca, maíz y arroz) como agentes formadores de poros en tecnología cerámica. Ellos han encontrado que, bajo cocción, los polímeros de almidón se queman sin dejar residuos y generan una estructura porosa cuyo tamaño y forma es determinada por el tipo de almidón adicionado. Demir et al. (21) investigaron la utilización de los residuos de la producción de pulpa de papel en la producción de ladrillos de arcilla para aumentar la capacidad de high bagasse waste addition to the clay body improves the thermal properties of the material but also has negative effects on the mechanical resistance of materials and may give rise to products with low compressive strength and a tendency to crack (20).

Water suction affects the quality and durability of the bricks. Bricks with high contents of bagasse may have defects and a clear tendency to water suction and therefore with lower durability. In agreement with the Standard procedure UNE 67019 the water suction must be inferior to $0,45 \mathrm{~g} / \mathrm{cm}^{2} \mathrm{~min}$. The results of the water suction test are shown in Table 2. Water suction in the case of pure clay is $0.14 \mathrm{~g} / \mathrm{cm}^{2} \min$. This value is preserved up to an incorporation of $5 w t \%$ of waste. New incorporations of bagasse of $7.5 w t \%$ and $10 w t \%$ in the clay body produce an increase in the water suction of 0.20 and $0.27 \mathrm{~g} / \mathrm{cm}^{2} \mathrm{~min}$, respectively. This indicates that addition of higher content in waste increases the surface interconnected porosity in accordance with the absorption data. Samples with lower residue content (2.5 and 5 wt\%) may thus have increase closed porosity caused by the formation of unconnected pores.

Morphological study of the samples containing clay, as well as that of samples containing larger or smaller amounts of bagasse (C-2.5B\%, C-5B\% and C-10B\%), was obtained by means of SEM, as shown in Figure 4.

The micrographs show clay porosity (Figure 4a), either small-sized and closed pores (micropores), resulting from intergrain porosity; or open pores (macropores), over the pores located in the surface. These changes are due to the presence of bagasse. Small amounts of bagasse (2.5 wt\% and 5 wt\%) cause an increase in closed porosity and pores with a regular spherical shape (Figures $4 b$ and $4 c$ ), while larger amounts of bagasse (> $5 w t \%)$ cause an increase in the open porosity as a result of the connection of macropores due to water absorption (Figure 4d).

Other authors have studied the introduction of organic wastes in clay brick production, Gregorová et al. (9) have studied the use of different types of starch (potato, wheat, tapioca, corn and rice starch) as pore-forming agents in ceramic technology. They have shown that, upon firing, the starch polymers are burnt without residues and leave a pore structure whose size and shape is determined by the type of starch applied. Demir et al. (21) have investigated the utilization of kraft pulp production residues in clay brick to increase the insulation capacity of the brick and to generate porosity in the clay body. The addition of 2.5 to 5 wt\% residue 


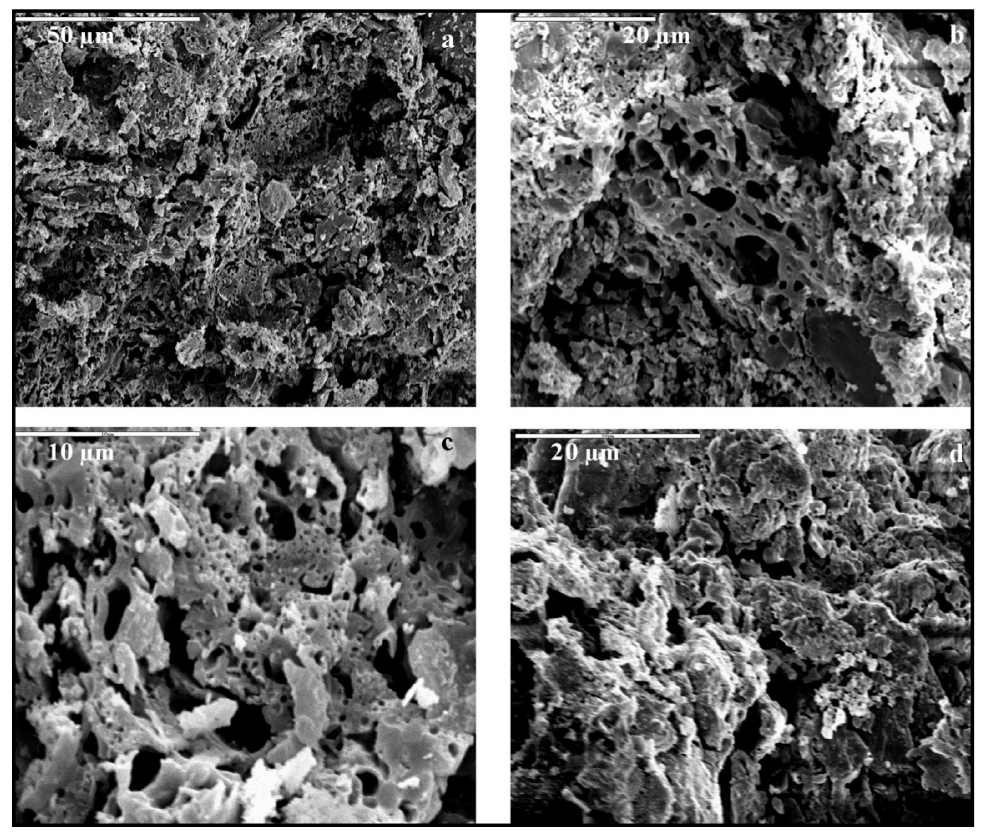

Figura 4. Micrografías SEM de (a) muestra de arcilla (b) muestra conteniendo 2,5\% en peso de bagazo y c) muestra conteniendo $10 \%$ en peso de bagazo.

Figure 4. SEM micrographs of (a) clay sample (b) sample containing 2.5 wt\% of bagasse and c) sample containing 10 wt\% of bagasse.

aislamiento del ladrillo y generar porosidad en el cuerpo de la arcilla. La adición del 2,5 al $5 \%$ en peso de residuo da lugar a ladrillos con aceptables propiedades mecánicas, siendo eficaz para la formación de poros en una pasta de arcilla. Posteriormente, Demir (10) estudió la incorporación de residuos orgánicos (aserrín, residuos de tabaco y hierba) a arcilla cruda. Los residuos orgánicos, hasta $5 \%$ en peso, pueden ser utilizados eficazmente para la formación de poros. Los residuos incrementan la porosidad abierta y disminuyen la densidad aparente, manteniendo propiedades mecánicas aceptables.

El ensayo de resistencia a la compresión es un ensayo importante para garantizar la calidad ingenieril de un material de construcción. Los resultados indican que la resistencia a la compresión depende en gran medida de la cantidad de bagazo en el ladrillo (Figura 5). Es importante señalar que la adición del $2,5 \%$ en peso de bagazo no produce casi ningún cambio en la resistencia a la compresión de la arcilla. Esto difiere de todas las otras composiciones investigadas, en las que la resistencia a la compresión de la arcilla pura (66,5 $\mathrm{MPa}$ ) disminuye con la adición de bagazo. La adición de más del $5 \%$ en peso de bagazo disminuye la resistencia a la compresión con respecto a los ladrillos de arcilla pura hasta un $75 \%$, obteniendo el menor valor de resistencia a la compresión de 16,2 MPa para la muestra C-10. La disminución de la resistencia a la compresión con el contenido de bagazo puede atribuirse a la reducción de la densidad en relación a la mayor porosidad generada por la combustión del residuo, lo cual va en detrimento de las propiedades mecánicas de los productos cerámicos (22). were found to be effective for forming pores in a clay body that have acceptable mechanical properties. Subsequently, Demir (10) studied the use of organic residues (sawdust, tobacco residues and grass) in raw brick clay. Organic residues can be effectively used for pore forming for up to $5 w t \%$ residue addition. The residues increased the open porosity and decrease the bulk density, while maintaining acceptable mechanical properties.

The compressive test is an important test for assuring the engineering quality of a building material. The results indicate that the strength depends greatly on the amount of bagasse in the brick (Figure 5). It is important to note that the addition of 2.5 wt\% of bagasse leads to almost no change in the compressive strength. This differs from all of the other compositions investigated, in which the compressive strength of the pure clay (66.5 $\mathrm{MPa}$ ) decreases with the addition of bagasse. Adding bagasse to brick containing more than 5\% decreases the compressive strength of pure clay to $75 \%$, obtaining the lowest compressive strength of $16.2 \mathrm{MPa}$ for sample $C-10 B$. The overall decrease in the compressive strength with the bagasse content can be attributed to the density reduction related to the greater porosity of the bodies, produced by the combustion of waste, which is detrimental to the mechanical properties of the ceramic (22). 


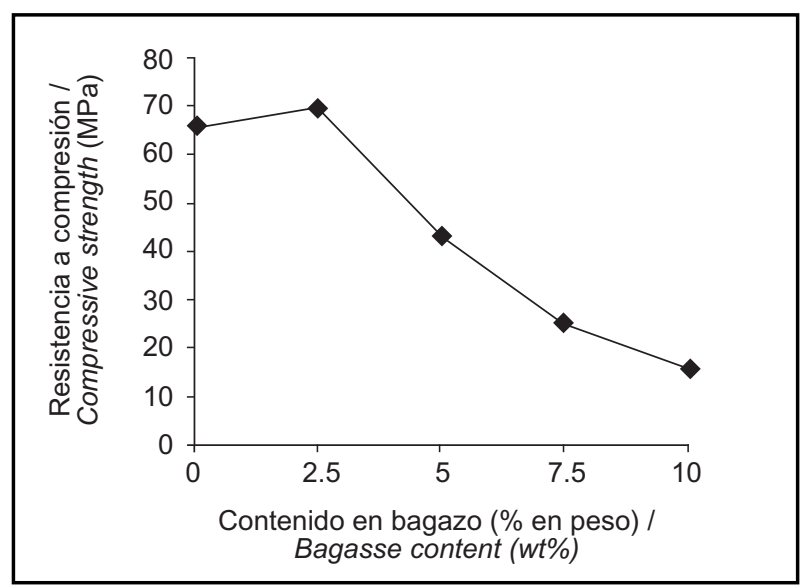

Figura 5. Resistencia a la compresión de los ladrillos en función de la cantidad de bagazo añadido. Figure 5. Compressive strength of bricks as a function of the amount of bagasse added.

Sin embargo, todas las composiciones presentan un valor de resistencia a la compresión superior al establecido por la Norma UNE 67046-88, que establece que la resistencia a la compresión de los ladrillos debe ser al menos de $10 \mathrm{MPa}$. La muestra C-2,5B muestra una reducción en la densidad aparente y absoluta y tiene propiedades mecánicas similares a la arcilla pura, probablemente debido al tipo de porosidad (cerrada) y al pequeño tamaño de sus poros, como muestra el estudio SEM.

Bartulli et al. (23) concluyen que las propiedades mecánicas de los ladrillos están muy influenciadas por el número total de poros, así como por la distribución de los poros dentro de la matriz sólida.

La heladicidad es un índice de susceptibilidad a ciclos sucesivos de hielo y deshielo. Completados los 25 ciclos, se procedió a la inspección ocular de las muestras y se comprobó que no se produjeron exfoliaciones, fisuras o desconchados (Figura 6).

Debido a que la resistencia al hielo-deshielo se caracteriza por la disminución de la resistencia a la compresión de las muestras antes y después de someterse a 25 ciclos de hielo y deshielo, se ha llevado a cabo un análisis comparativo
Nevertheless, all of the compositions present a value of compressive strength higher than UNE Standards, which establish that the compressive strength of bricks must be at least $10 \mathrm{MPa}$. The $\mathrm{C}-2.5 \mathrm{~B}$ sample shows a reduction in bulk and absolute density and has mechanical properties similar to pure clay, probably due to its porosity type (closed) and the small-sized pores, as the SEM study shows.

Bartulli et al. (23) conclude that the mechanical properties of brick are highly influenced by the total number of pores, as well as the distribution of cavities within the solid matrix.

Frost resistance is an index of the ability to withstand a series of consecutive freeze-thaw cycles. A visual examination of all 25 cycles implemented on samples revealed no exfoliation, fissures or spalls (Figure 6).

Because frost resistance is characterized by the decrease in compressive strength of samples before and after undergoing a series of 25 freeze-thaw cycles, a comparative trial on compressive strength was

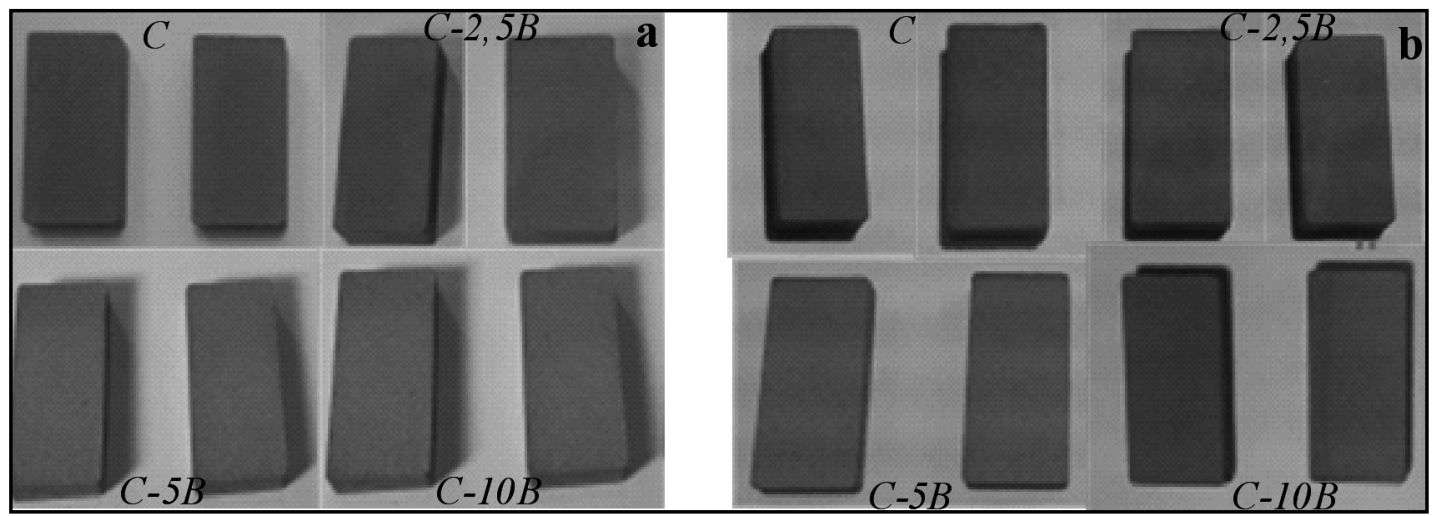

Figura 6. Muestras (a) antes y (b) después de la prueba de resistencia a la congelación. Figure 6. Samples (a) before and (b) after frost resistance trial. 


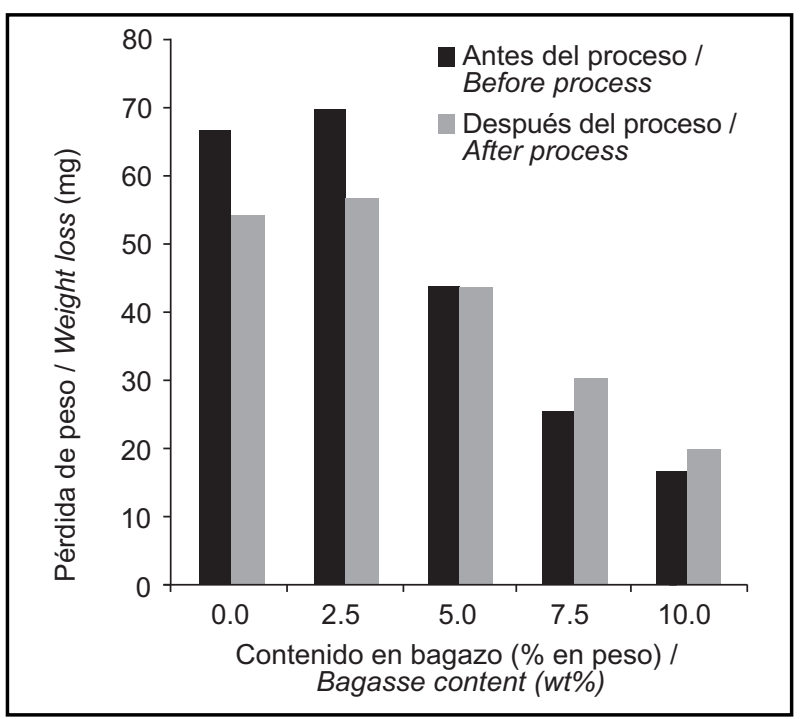

Figura 7. Resistencia a la compresión antes y después de la prueba de resistencia a la congelación. Figure 7. Compressive strength before and after frost resistance trial.

de la resistencia a la compresión. Los resultados indican que la resistencia a la compresión apenas se ve afectada después del ensayo de congelación-descongelación (Figura 7).

\section{CONCLUSIONES}

Este trabajo ha demostrado la posibilidad de reciclar el bagazo de la industria de la cerveza mediante su inclusión en la matriz cerámica. El uso del bagazo en la industria cerámica es beneficioso al incorporar las propiedades energéticas asociadas con el contenido de materia orgánica del residuo. La proporción de residuo es un factor clave que afecta a las propiedades tecnológicas de los ladrillos. La incorporación de cantidades crecientes de bagazo en el cuerpo de la arcilla aumenta la porosidad abierta y disminuye la densidad aparente. Este efecto puede mejorar las propiedades de aislamiento térmico. Aunque la resistencia a la compresión de las muestras cocidas disminuye con la adición del residuo, los valores son aún mayores que las exigidas por las normas UNE. En resumen, la proporción de bagazo recomendada para producir ladrillos de buena calidad es del 2,5\% en peso cocidos a $950^{\circ} \mathrm{C}$ (1 hora). El ladrillo C-2,5B tiene una menor densidad aparente y una resistencia a la compresión similar a la arcilla pura, probablemente debido a su mayor porosidad cerrada y al pequeño tamaño de los poros, como muestra el estudio SEM.

\section{AGRADECIMIENTOS}

El apoyo financiero para esta investigación fue obtenido bajo el Proyecto UJA_07_17_05, RFC/ PP2006/Id_684 (Plan Propio de la Universidad de Jaén), por lo que estamos muy agradecidos. Asimismo, los autores agradecen implemented. The results indicate that the compressive strength was barely affected after the freeze-thaw test (Figure 7).

\section{CONCLUSIONS}

This work has demonstrated the possibility of recycling bagasse from the beer industry by including it in the ceramic matrix. The use of bagasse in the ceramics industry is beneficial to incorporating the energetic properties associated with organic matter content containing the residue. The results of our study indicated that the incorporation of increasing amounts of bagasse in the clay body increased the open porosity and decreased the bulk density. This effect may improve the thermal insulation properties. Although the compressive strength of the fired samples decreased with the addition of the residue, the values were still higher than required by UNE Standards. In sum, the proportion of bagasse recommended to produce good-quality brick is $2.5 \mathrm{wt} \%$ fired at $950^{\circ} \mathrm{C}$ (1 hour). The C-2.5B brick shows lower bulk density and similar compressive strength to pure clay, probably due to its higher closed porosity and the small-sized pores, as the SEM study shows.

\section{ACKNOWLEDGEMENTS}

Financial support for this research was obtained under Project UJA_07_17_05, RFC/ PP2006/Id_684 (University of Jaén Own Plan), for which we are very grateful. As well as, the authors thank Heineken brewery of Jaén 
a la cervecera Heineken de Jaén (España) el suministro de residuo bagazo y a los Servicios Técnicos de Investigación de la Universidad de Jaén por el apoyo prestado en la determinación de algunas de las propiedades determinadas.
(Spain) for the supply of residue bagasse. And to Technical Research Services from UJA for provided help in the determination of some ones determined properties.

\section{BIBLIOGRAFÍA / BIBLIOGRAPHY}

(1) European Environment Agency: "Time for action towards sustainable consumption and production in Europe" (2007), http://www.eea.europa.eu

(2) European Commission: "Report from the commission to the council and the European Parliament on implementation of the Community waste legislation". COM (2006), 406[final Brussels].

(3) Khoo, H. H.: "Life cycle impact assessment of various waste conversion technologies", Waste Manag., 29 (2009), pp. 1892-1900. http://dx.doi.org/10.1016/j.wasman.2008.12.020

(4) Hartlén, J.: "Environmental consequences of using residues", Waste Manag., 16 (1996), pp. 1-6. http://dx.doi.org/10.1016/S0956053X(96)00024-4

(5) Ashby, M. F., "Drivers for material development in the 21st century", Prog. Mater. Sci., 46 (2001), pp. 191-199. http://dx.doi.org/ 10.1016/S0079-6425(00)00014-1

(6) Balgaranova, J.; Petrov, A.; Pavlova, L.; Alexandrova, E.: "Utilization of wastes from the coke-chemical production and sewage sludge as additives in the brick-clay", Water Air Soil Pollut., 150 (2003), pp. 103-111. http://dx.doi.org/10.1023/A:1026190417523

(7) Zalygina, O. S.; Barantseva, S. E.: "The use of excess activated sludge from municipal sewage treatment works in production of construction ceramics", Glass Ceram., 55 (1998), pp. 164-167. http://dx.doi.org/10.1007/BF02694733

(8) Lemeshev, V. G.; Petrov, S. V.; Lemesev, O. V.: "Utilization of technogenic products in production of ceramic building materials", Glass Ceram., 58 (2001), pp. 93-96. http://dx.doi.org/10.1023/A:1010943314294

(9) Gregorová, E.; Pabst, W.; Bohaãenko, I.: "Characterization of different starch types for their application in ceramic processing", J. Eur. Ceram. Soc., 26 (2006), pp. 1301-1309. http://dx.doi.org/10.1016/j.jeurceramsoc.2005.02.015

(10) Demir, I.: "Effect of organic residues addition on the technological properties of clay bricks", Waste Manag., 28 (2008), pp. 622627. http://dx.doi.org/10.1016/j.wasman.2007.03.019

(11) Instituto Tecnológico Agroalimentario (AINIA): "La industria cervecera" (1999), http://www.prtr-es.es/data/images/la\%20industria\%20cervecera-74f8271308c1b002.pdf

(12) Ministerio de Agricultura Pesca y Alimentación (MAPA): "Guía de las mejores técnicas disponibles en España del Sector Cervecero" (2005), http://www.mapa.es/alimentacion/pags/industria/medio_ambiente/guias_mtd/sector_cervecero.pdf

(13) UNE-EN 77213: "Determinación de la densidad absoluta seca y de la densidad aparente seca de piezas para fábrica de albañilería (excepto piedra natural)/Determination of net and gross dry density of masonry units (except for natural stone)".

(14) UNE 67027: "Ladrillos de arcilla cocida. Determinación de la absorción de agua/Burned clay bricks. Determination of the water absorption".

(15) UNE 67031: "Ladrillos de arcilla cocida. Ensayo de succión/Burned clay bricks. Suction test".

(16) UNE 67028: "Ladrillos cerámicos de arcilla cocida. Ensayo de heladicidad/Clay bricks. Freezing test".

(17) Canseco-Medel, A.: "Tecnología de combustibles", 2 vol. (1978), Madrid, Fundación Gómez-Pardo.

(18) Freyburg, S.; Schwarz, A.: "Influence of the clay on the pore structure of structural ceramics", J. Eur. Ceram. Soc., 27 (2006), pp. 1727-1733. http://dx.doi.org/10.1016/j.jeurceramsoc.2006.04.158

(19) Kingery, W. D.; Bowen, H. K.; Ulkmann D. R.: "Introduction to ceramics", 2nd ed. (1975), New York, Jonh Wiley \& Sons.

(20) Tufiño, G.; Vieira, L. L.; Guerrero, V.: "Propiedades térmicas de arcillas para ser utilizadas como material refractario" (2007), Centro de Desarrollo Tecnológico Sustentable, Escuela Politécnica Nacional de Quito (Ecuador).

(21) Demir, I.; Baspina, M. S.; Orhab, M.: "Utilization of kraft pulp production residues in clay brick production", Build. Environ., 40 (2005), pp. 1533-1537. http://dx.doi.org/10.1016/j.buildenv.2004.11.021

(22) Carty, W. M.; Senapati, U.: "Porcelain-raw materials, processing, phase evolution, and mechanical behavior", J. Am. Ceram. Soc., 81 (1) (1998), pp. 1-18. http://dx.doi.org/10.1111/j.1151-2916.1998.tb02290.x

(23) Bartuli, C.; Bemporad, E.; Tulliani, J. M.; Tirillò, J.; Pulci, G.; Sebastiani, M.: "Mechanical properties of celular ceramics obtained by gel casting: Characterization and modeling", J. Eur. Ceram. Soc., 29 (2009), pp. 2979-2989. http://dx.doi.org/10.1016/j.jeurceramsoc.2009.04.035 